\title{
Deacidification of Camelina sativa $L$. seed oil by Physisorption method and characterization of produced biodiesel
}

\author{
Rakshit Pathak* \\ Department of Chemistry, D. S. B. Campus, Kumaun University, Nainital-26300 (Uttarakhand), \\ India \\ Kritika Guleria \\ Defence Institute of Bio-Energy Research (DRDO), Haldwani, Nainital- 263139 (Uttarakhand), \\ India. \\ Anjali Kumari \\ Defence Institute of Bio-Energy Research (DRDO), Haldwani, Nainital- 263139 (Uttarakhand), \\ India.

\section{Satya Pal Singh Mehta} \\ Department of Chemistry, D. S. B. Campus, Kumaun University, Nainital-26300 (Uttarakhand), \\ India \\ *Corresponding author. Email: rakshitpathak325@gmail.com
}

\section{How to Cite}

\section{Article Info}

https://doi.org/10.31018/ jans.v13i1.2555

Received: February 5, 2021

Revised: March 7, 2021

Accepted: March 11, 2021

Pathak, R. et al. (2021). Deacidification of Camelina sativa L. seed oil by Physisorption method and characterization of produced biodiesel. Journal of Applied and Natural Science, 13(1): 287 - 294. https://doi.org/10.31018/jans.v13i1.2555

\begin{abstract}
According to India's National Biofuel Policy, only non-edible oilseed crops can be used for the biofuel feedstock. In this context, Camelina sativa is one such plant that fulfils all the criteria defined by the Biofuel policies of India. So, the present investigation was aimed to examine $C$. sativa seed oil capabilities as a biodiesel feedstock. Oil was deacidified via adsorption method applying Silica Gel as an adsorbent. The highest efficacy was obtained when 1:9 (Silica gel: oil) ratio was applied and the acid value was reduced from 6.45 to $2.78 \mathrm{mg} \mathrm{KOH} / \mathrm{g}$. Furthermore, oil was transesterified using methanol in the ratio of 1:6 (oil: methand molar ratio) and $0.8 \%$ (w/w of oil) of $\mathrm{KOH}$ as a catalyst at $70{ }^{\circ} \mathrm{C}$. The produced biodiesel was analyzed in terms of fuetspecific parameters and results were compared with American Society for Testing and Materials (ASTM) standards. The results were very much satisfactory and under the limits specified by the ASTM standards. The results revealed that oil to biodiesel conversion was $92.28 \%$ with an acid value of $0.37 \mathrm{mg} \mathrm{KOH} / \mathrm{g}$. The measured lodine value was $152 \mathrm{gl} / 100 \mathrm{~g}$ indicated the high unsaturation. Still, Camelina biodiesel showed oxidation stability of $6 \mathrm{~h}$., which was a decent value compared to this much unsaturation. The sulphur content was also higher $(24 \mathrm{ppm})$ than the specified limit (15 ppm). Besides, the fuel-specific parameters like sulphur content and iodine value were under the ASTM limits.
\end{abstract}

Keywords: Acid value, Biodiesel, Camelina sativa, Silica gel, Transesterification

\section{INTRODUCTION}

The fuel sector is the backbone of modern civilization and therefore, extensive research is going on everywhere in the world to ensure the availability of fuels for industries and transportation. As an emerging country, India is also a very big consumer of petroleum products and fulfils its own energy demand by importing crude oil from other countries (Dalei, 2017; Sbesta 2020). This dependency is often reduced by developing alternative fuel sources that should be cost-effective and environment friendly. In this context, biodiesel is grasping all the scientific community's attention to overcome such scarcity of petroleum products. There is number of biomass utilized as a feedstock for biodiesel production, e.g. vegetable oils, creature fats, algae, cyanobacteria, waste cooking oil and some non-edible raw materials (Pinzi, 2014; Mamat et al., 2019).

According to India's National Biofuel policy, only nonedible oil plants should be preferred for biodiesel production (Biofuel Policy, 2018). Considering this policy, the present study was focused on evaluating the biodiesel capabilities of a renowned non-edible oilseed crop Camelina sativa $L$. in Indian climatic conditions. 
Camelina sativa (Fig. 1) is a dicotyledonous, terrestrial oil seeded species of the Brassicaceae family that originated in Germany about 600 B.C. and later widen to central Europe and south west of Asia (Berti et al., 2016). It is a short seasoned annual crop with anchoring roots; plants are tall and range up to height $80-90$ $\mathrm{cm}$., leaves are smooth or with few hairs and without having petioles and attached with the stems in an alternate manner (Richard, 2011). One of the major qualities of Camelina is that it easily adapts to any climatic conditions and environment. In addition to this, the plant needs less amount of water, manure and pesticides and contains oil yield from the range 32-38 \% (Kumar and Pathak, 2016). However, Camelina seed oil yield and its fatty acid composition are largely varied in different environmental conditions (Murphy, 2016). The study was also interesting as in India; biodiesel study is so far focused on Jatropha curcas; a high oil yielding perennial plant from the family Euphorbiaceae (Pandey et al., 2012). Except for the Defence Institute of BioEnergy Research (DIBER) laboratory, Camelina oilrelated research work has not been given much importance to date in India. Hence, in the present investigation, efforts were attempted to evaluate the ester -specific and fuel-specific biodiesel characteristics produced from Camelina seed oil. It is also important to mention here that for the refining of Camelina oil first time, Silica Gel (SG) was used as a deacidifying agent. The efforts were also made to analyze the efficacy of silica gel for removing free fatty acids from the Camelina oil.

\section{MATERIALS AND METHODS}

The present investigation was carried out at the Defence Institute of Bio Energy Research, Haldwani, Uttarakhand, in India. Camelina sativa cv. Calena (EC643910) were collected from DIBER field Station, Haldwani, Uttarakhand $\left(29.22^{\circ} \mathrm{N} 79.52^{\circ} \mathrm{E}\right)$ and were dried for 2 days in a hot air oven. Seeds were ground into fine particles for the oil estimation. All the chemicals required for the experiments were analytical grade (AR) procured from the local vendor and used without further purification.

\section{Oil estimation}

Camelina seed oil was obtained using mechanical expeller followed by the solvent extraction method via Soxhlet apparatus using hexane as a non-polar solvent. Excess of solvent was removed using Rota-evaporator, the oil was accurately weighed and the acid value was estimated prior to the deacidification process.

\section{Deacidification of oil}

Blue crystalline silica gel was used for deacidification based on its adsorption capability of the moisture
(Christy, 2012; Wang et al., 2014). Prior to the use, Silica Gel (SG) was activated in hot air oven at $120{ }^{\circ} \mathrm{C}$ and grounded into a fine powder using a mixture grinder. $1000 \mathrm{~mL}$ of a glass beaker was used for the adsorption phenomena. Oil was mixed with hexane in a ratio of $10: 1(\mathrm{~g} / \mathrm{g})$ to reduce the viscosity of the oil by which it can react easily with the SG. SG was poured into this mixture in four different SG ratio to oil ratio (1:3,1:6,1:9 and 1:12) and stirred (900 rpm) on a magnetic stirrer for $1 \mathrm{~h}$. Finally, SG was settled down and the oil mixture was decanted and filtered using Whatman filter paper. The entire process was repeated three times and was compared based on oil percentage, acid value (AV), free fatty acid value (\% FFA) and density.

\section{Oil conversion to biodiesel}

$500 \mathrm{~g}$ of refined oil was poured into a round bottom flask and preheated at $60{ }^{\circ} \mathrm{C}$ using water bath prior to the TE reaction. TE reaction was done with methanol to oil molar ratio 6:1 \{103.29 g of Methanol (calculated theoretically using average molar mass of the oil)\}, $4 \mathrm{~g}$ ( $0.8 \% \mathrm{w} / \mathrm{w}$ of oil) of $\mathrm{KOH}$ was added to the mixture and heated at $70{ }^{\circ} \mathrm{C}$ for $1 \mathrm{hr}$. followed by the continuous stirring $(400 \mathrm{rpm})$ using magnetic stirrer. Presuming the completion of reaction, the reaction mixture was transferred into the separating funnel and allowed to settle overnight into two different layers. The bottom layer of glycerol was separated from the upper layer of produced biodiesel, followed by the washing with DW to remove water-soluble impurities. Yield conversion was calculated by the following formula:

$$
\mathrm{BD} \text { Yield (in \%) }=\frac{\text { Weight of obtained biodiesel }}{\text { Weight of oil used for TE }} \times 100
$$

\section{Characterization of produced biodiesel}

TLC of the oil and produced biodiesel was done by using CAMAG HPTLC (Make: Switzerland), oil samples were dissolved in methanol and applied on the TLC plate (60 F 254 Merck) by using syringe injector Linomat $\mathrm{V}$ (injecting speed: - $150 \mathrm{nl} / \mathrm{sec}$ with the help of nitrogen), the mobile solvent was Hexane: DEE: AA $(8.5: 1.5: 0.1 \mathrm{v} / \mathrm{v} / \mathrm{v})$ and after complete running of solvent, plate was dried under the chamber and derivatized using iodine granules. Whole process was worked under regular laboratory conditions (Temp. $25 \pm$ $2{ }^{\circ} \mathrm{C}, \mathrm{RH} 50 \pm 5 \%$ ).

For determining the functional group, Fourier Transform Infrared Spectroscopy (FT IR) spectra of Camelina Biodiesel (CBD) was recorded on FT-IR Spectrometer (Model: Bruker Alpha II, GmbH, Make: Germany) in spectral range $4000-500 \mathrm{~cm}^{-1}$. Results were evaluated using OPUS software. Gas Chromatography-Mass Spectrometry (GC-MS) profiling of CBD was also analyzed to know the Mono Unsaturated Fatty Acids 
(MUFA) and Poly Unsaturated Fatty Acid (PUFA) components percentage. For this purpose, the sample was analyzed in GC MS QP-2010 model (Shimadzu, Japan) and final mass spectra were compared with the NIST14 library.

\section{Physicochemical characterization}

Transeterified Camelina oil was characterized on the basis of different ester specific and fuel-specific properties. The results were compared with the limits specified by the American Society for Testing and Materials, ASTM D (2002) 6751-02.

\section{Moisture content, sp. gravity, RI estimation}

Moisture content was estimated using Halogen Moisture Analyzer (Mettler TOLEDO HE 53). Specific gravity of the samples was determined using Density/ Specific Gravity Meter (DA- 130N). The Refractive Index (RI) of the samples was estimated by Refractometer (Kyoto electronics RA - 600).

\section{Determination of acid value and FFA\%}

The acid value was determined using the American Oil Chemist's Society (AOCS) official method Cd 3a-63 (AOCS, 2004). $1 \mathrm{~g}$ of the sample was dissolved in 10 $\mathrm{mL}$ of ethanol followed by adding 1 drop of Phenolphthalein and titrated against $0.1 \mathrm{~N} \mathrm{KOH}$ solution, and endpoint occurred when the mixture colour appeared pink.

$$
\begin{aligned}
& \operatorname{AV}(\mathrm{mg} \mathrm{KOH} / \mathrm{g})=\frac{56.1 \times \mathrm{V} \times \mathrm{N}}{\mathrm{W}} \times 100 \\
& \operatorname{FFA}(\%)=\frac{0.282 \times \mathrm{V} \times \mathrm{N}}{\mathrm{W}} \times 100
\end{aligned}
$$

Where, $\mathrm{V}=$ titre value $(\mathrm{KOH}$ volume), $\mathrm{N}=$ Normality of $\mathrm{KOH}, \mathrm{W}=$ mass of oil, $0.28=$ Constant value (mass of oleic acid neutralized by $1 \mathrm{~g}$ of $\mathrm{KOH}$ ).

\section{Determination of saponification value (SV)}

SV value was determined by the method of (Barret, 2018). Oil was precisely measured and poured into a conical flask followed by adding ethanolic $\mathrm{KOH}$ and the mixture was refluxed in a water bath for 60 minutes. Complete saponification occurred and indicated by the clear appearance of the solution. Phenolphthalein was added to this mixture solution colour become pink. This mixture was titrated against $0.5 \mathrm{~N} \mathrm{HCl}$, endpoint observed when pink colour completely disappeared, the blank was also titrated against $0.5 \mathrm{~N} \mathrm{HCl}$. SV was calculated by the following formula: -

$$
\mathrm{SV}(\mathrm{mgKOH} / \mathrm{g})=\frac{56.1 \times(\mathrm{B}-\mathrm{S}) \times \mathrm{N}}{\mathrm{W}}
$$

Where, $B=$ titre value of $0.5 \mathrm{~N} \mathrm{HCl}$ required for the blank, $S=$ titre value of $0.5 \mathrm{~N} \mathrm{HCl}$ required for the sample, $\mathrm{N}=$ normality of $\mathrm{HCl}, \mathrm{W}=$ Mass of the sample. From the SV, the molecular mass of the oil was also determined using the following formula:

$$
\mathrm{MW}_{\text {oil }}=\frac{3 \times 56,100}{\mathrm{SV}}
$$

\section{Determination of iodine value (IV)}

lodine value was determined by the Wijs solution method (Zaliha et al., 2004). Oil samples were precisely weighed in an lodine flask and Wijs solution was added to it in a specific amount, reaction mixture was placed into a dark chamber for 1 hour. After this, potassium iodide solution and DW was added, the resultant solution was titrated against $0.1 \mathrm{~N}$ sodium thiosulfate solution till the yellow colour almost became colourless. After that, 2 to 3 drops of the starch solution were added to it and again titrated till the blue colour completely disappeared. The same procedure was followed using a blank sample. The amount of sodium thiosulfate required for blank minus the amount required for the oil sample gives the value of thiosulfate equivalent of lodine absorbed by the sample. Iodine value calculated by the formula: -

$$
\mathrm{IV}\left(\mathrm{gI}_{2} / 100 \mathrm{~g}\right)=\frac{\mathrm{N} \times(\mathrm{B}-\mathrm{S}) \times 12.69}{\mathrm{~W}}
$$

Where, $B=$ titre value of thiosulfate solution for the blank, $S=$ titre value of thiosulfate solution for the sample, $\mathrm{N}=$ Normality of thiosulfate solution, $12.69=$ Constant feach $\mathrm{mL}$ of sodium thiosulfate solution is

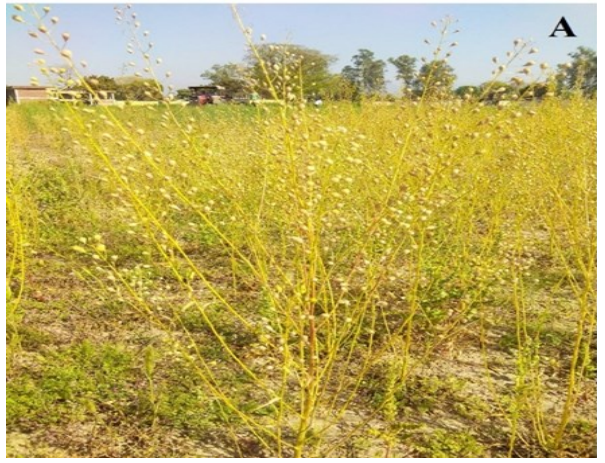

Fig. 1. (A). Camelina Plant at DIBER, Haldwani; (B). Camelina seeds. 
equivalent to $12.69 \mathrm{mg}$ of available iodine (Barabas and Brittain, 1998).

\section{Determination of peroxide value (PV)}

$1 \mathrm{~g}$ of sample was added with $1 \mathrm{~g}$ of $\mathrm{KI}$ in boiling test tube followed by adding $10 \mathrm{~mL}$ of the solvent mixture (2: 1 Glacial AA: Chloroform), reaction mixture was boiled in a water bath only for $30 \mathrm{sec}$, and immediately mixture was transferred to the flask which already filled with 20 $\mathrm{mL}$ of $5 \% \mathrm{KI}$ solution, the mixture was titrated against sodium thiosulfate solution by adding starch as an indicator, end point was observed when yellow colour completely disappeared. Same procedure was followed for the blank sample (Onukwuli et al., 2017). PV was calculated by the formula: -

$$
\mathrm{PV}(\mathrm{Meq} / \mathrm{Kg})=\frac{1000 \times \mathrm{N} \times(\mathrm{S}-\mathrm{B})}{\mathrm{W}}
$$

Where, $B=$ titre value of thiosulfate solution for the blank, $S=$ titre value of thiosulfate solution for the sample, $\mathrm{W}=$ mass of the sample.

\section{Statistical analysis}

All the experiments were done in triplicates and data were analyzed using SPSS 16.0 software. The means values were compared by the least significant difference (LSD) test at a significance level of $P \leq 0.05$. Equations were written using Microsoft Equation 3.0.

\section{RESULTS AND DISCUSSION}

\section{Characterization of Camelina oil}

The observed oil percentage from Camelina sativa seeds was $37.796( \pm 0.566)$ with a clear yellow appearance. The $C$. sativa is a short seasoned biennial herb, so this oil yield made it a worthy feedstock for biodiesel production. Since the AV and FFA \% were higher, oil cannot be used directly for TE's reaction (Table 1). To reduce these values, the refining of the oil was necessary prior to the use of Camelina oil for biodiesel production.

\section{Oil recovery and acid value (AV) reduction after} deacidification

Deacidification or neutralization method was used to remove various non-glyceride contents from the Camelina oil, which are responsible for the deterioration of oil or act as a barrier during the conversion of oil into biodiesel. For removing such substances from the Camelina oil, an adsorption (Physisorption) method was applied.

Four different oil: SG ratios $(3: 1,6: 1,9: 1$ and 12:1) were used for the deacidification. The highest AV, FFA $\%$ and density were reduced when the 3:1 ratio was applied (Fig. 2). However, the recovered oil percentage was lower than the other trials in the case of 3:1 (Figure 3). The recovered oil percentage was
Table 1. Physicochemical properties of Camelina seed oil.

\begin{tabular}{lll}
\hline Characteristics & Unit & Findings \\
\hline Colour & - & Yellow liquid \\
Odor & - & Agreeable \\
Oil Yield & $(\%)$ & $37.796( \pm 0.566)$ \\
Moisture & $(\%)$ & $0.038( \pm 0.0026)$ \\
Density & $\mathrm{g} / \mathrm{cm}^{3}$ & $0.921( \pm 0.0028)$ \\
RI & - & $1.423( \pm 0.0011)$ \\
AV & $\mathrm{mg} \mathrm{KOH} / \mathrm{g}$ & $6.453( \pm 0.075)$ \\
FFA & $(\%)$ & $3.226( \pm 0.375)$ \\
SV & $\mathrm{mg} \mathrm{KOH} / \mathrm{g}$ & $181.36( \pm 0.468)$ \\
IV & $\mathrm{gl}_{2} / 100 \mathrm{~g}$ & $157.12( \pm 1.343)$ \\
\hline
\end{tabular}

Each Value expressed as mean, \pm S. D. $(n=3)$

highest when the 12:1 ratio was applied (87.91\%), but the acid value was not much reduced in this case. Results concluded that considering all the parameters, 9:1 proportion was obviously better because it involved less quantity of SG and high yield of oil, was recovered (82.92 \%). AV and \% FFA $(2.78,1.39 \%)$ were also much reduced using this proportion (Fig. 2 and 3 ).

Results showed the efficiency of SG to trap the free fatty acids and non-glyceride substances present in the Camelina oil. The study also concluded that the deacidification of vegetable oil using SG was very simple and environmentally friendly compared to alkali or acid treatment in which excess of water is required.

\section{Characterization of produced biodiesel}

After completion of the whole process, the obtained CBD yield was $92.28 \%$. Crude Camelina seed oil was dark yellow in colour and it was very viscous before any treatment. After deacidification, Deacidified Camelina sativa Oil (DCSO) colour became light yellow and after TE, oil colour became light brown. It primarily indicated that the reaction proceeded successfully. Furthermore, HPTLC imaging was also developed for all three different oils and it clearly showed the triglyceride (TG) and fatty acid methyl ester (FAME) component at different $R_{f}$ values (Figure 4). FT IR of obtained trans esterify oil also confirmed that the reaction succeeded successfully. In the spectrum, several peaks occurred at a noticeable region (Figure 5). An intense band at $1747.51 \mathrm{~cm}^{-1}$ showed the characteristic of aliphatic ester $\mathrm{C}=\mathrm{O}$ bond (FAME; i.e. biodiesel) initially confirmed the formation of biodiesel. Stretching vibrations of $\mathrm{CH}_{3}, \mathrm{CH}_{2}$ and $\mathrm{CH}$ appeared at $2852.91 \mathrm{~cm}^{-1}$, $2927.91 \mathrm{~cm}^{-1}$ and $3006.16 \mathrm{~cm}^{-1}$, whereas $723 \mathrm{~cm}^{-1}$, 1173-1196 cm and $1356 \mathrm{~cm}^{-1}$ showed the characteristic banding vibrations of these groups. A signal at $1434.8 \mathrm{~cm}^{-1}$ showed the stretching vibration of $\left(-\mathrm{OCH}_{3}\right)$ methyl ester group. 


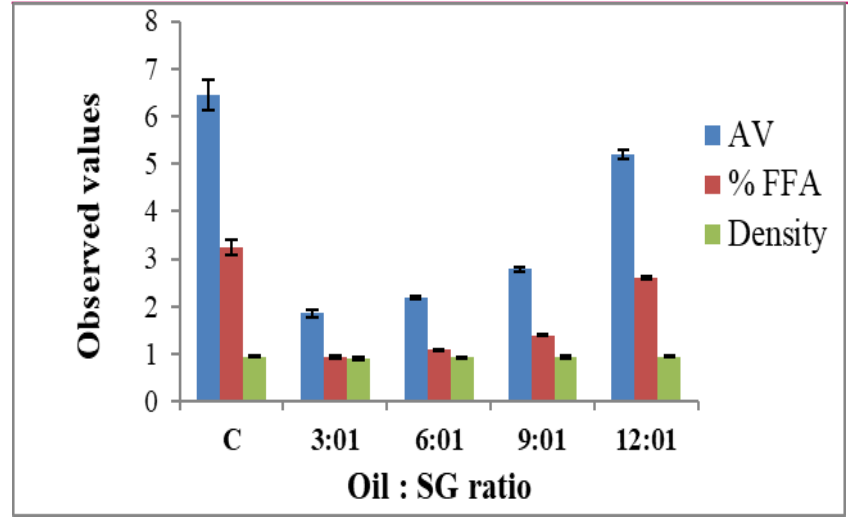

Fig. 2: Different parameters on applying SG: oil ratio.

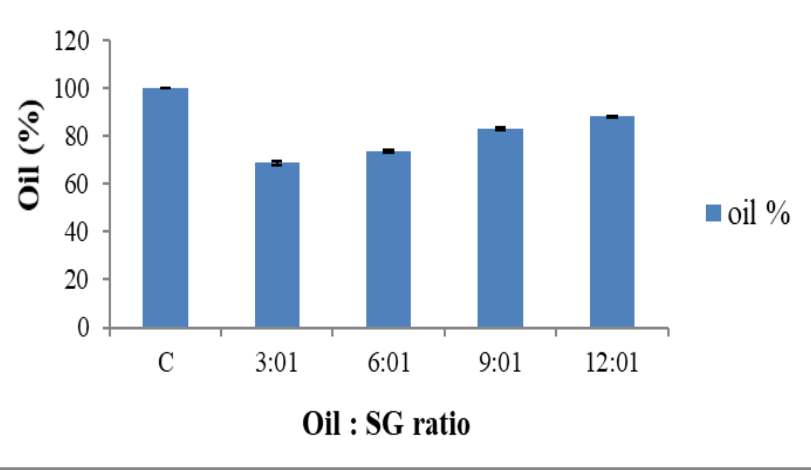

Fig. 3. Recovered oil percentage after deacidification treatment.

Table 2. Fatty acid composition of obtained biodiesel from Camelina oil.

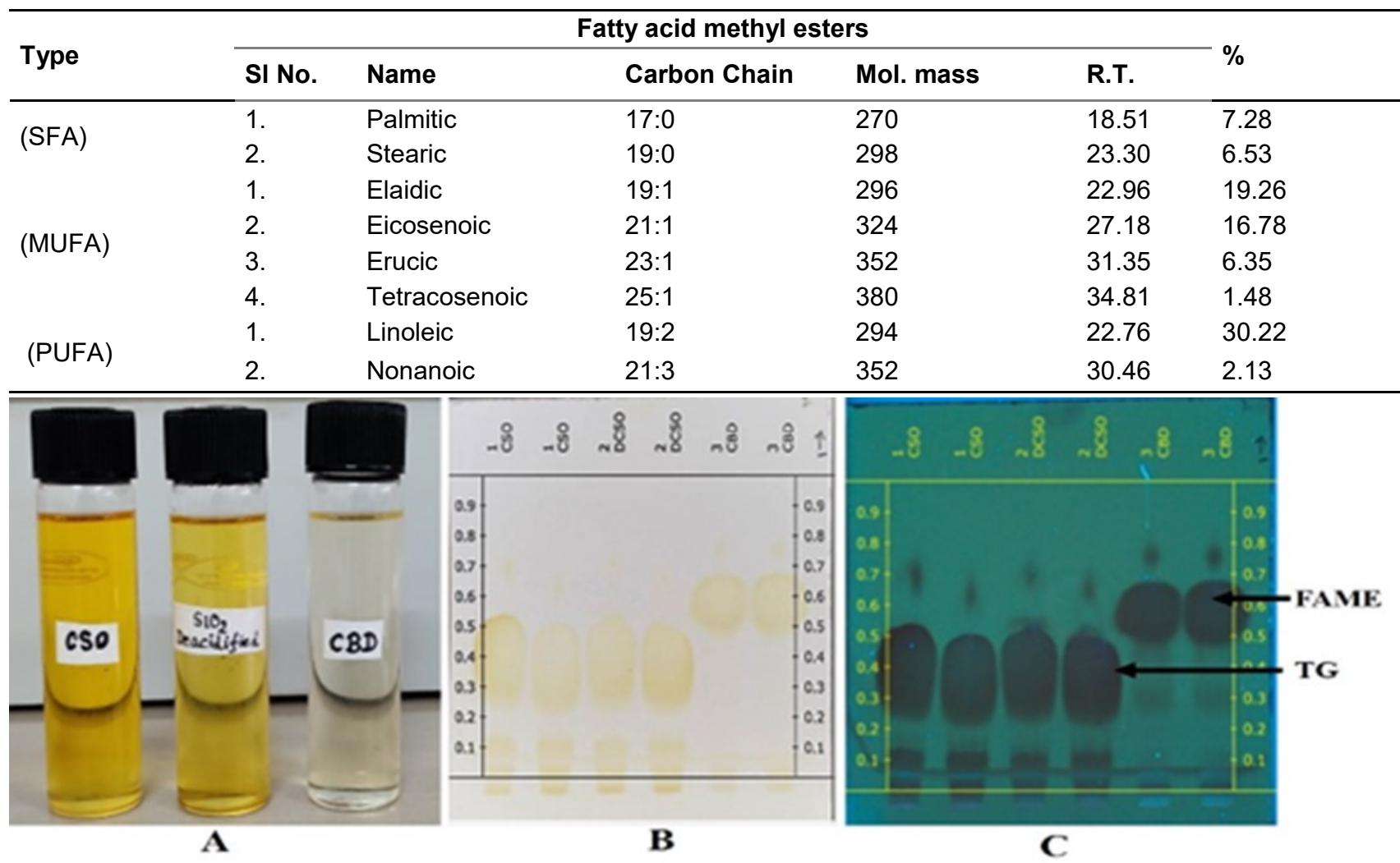

Fig. 4. A: Showing colour appearance of oils; B: - HPTLC image of the oil and BD in white light, C: - HPTLC image of the oil and $B D$ at wavelength $254 \mathrm{~nm}$.

The fuel-specific properties of biodiesel solely depend upon its fatty acid constituents, and Camelina oil exhibits different fatty acid compositions at different climatic conditions and environment (Murphy, 2016). So, there was a need to know the fatty acid composition of the obtained biodiesel. In CBD, the number of MUFA and PUFA components is present in higher amounts compared to other oilseed crops such as Jatropha curcas, Pongamia pinnatae, Heavea brasiliensis and Azadiracta indica etc (King et al., 2009; Demirbas et al., 2016). Camelina produced biodiesel containing almost $66 \%$ of unsaturated fatty acids, as by the GC-MS graph shown in Figure 6. In terms of carbon chain length, C-20 and it above chain length fatty acids were almost $26 \%$ (Table 2). Higher unsaturation of Camelina oil is a major drawback to make it a worldclass feedstock for biodiesel production. However, the fatty acid composition can be reduced by the genetic modification to their seed varieties (Villanueva-Mejia et al., 2017).

Unsaturated fatty acids are less stable than saturated oils and the presence of double bond makes them more susceptible to rancidity. Rancidity is the oxidation of oil and the produced oxidative components deteriorate the chemical properties of the oil. However, these oxidations can be reduced by packaging the 


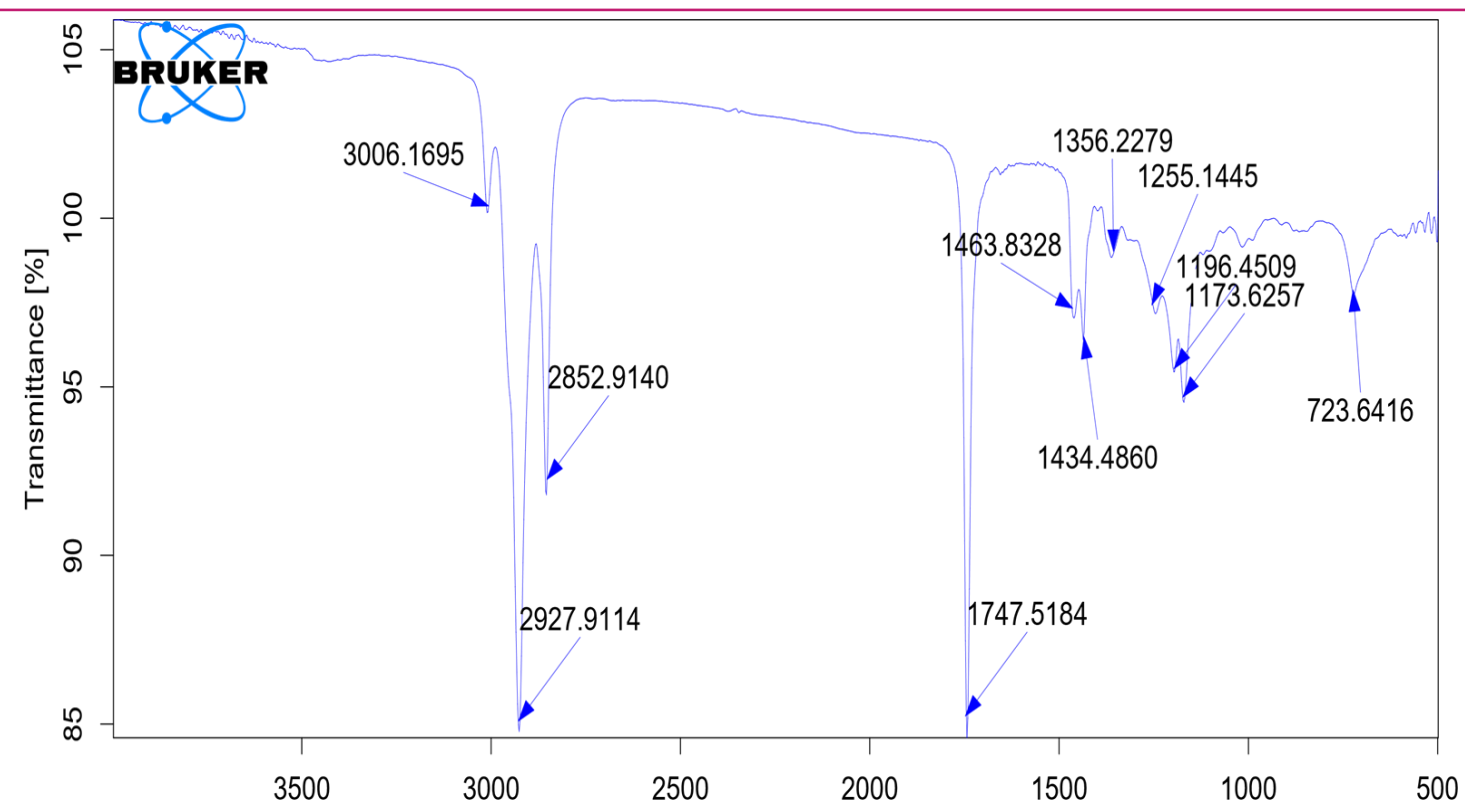

Fig. 4. FT-IR spectrum of produced biodiesel.

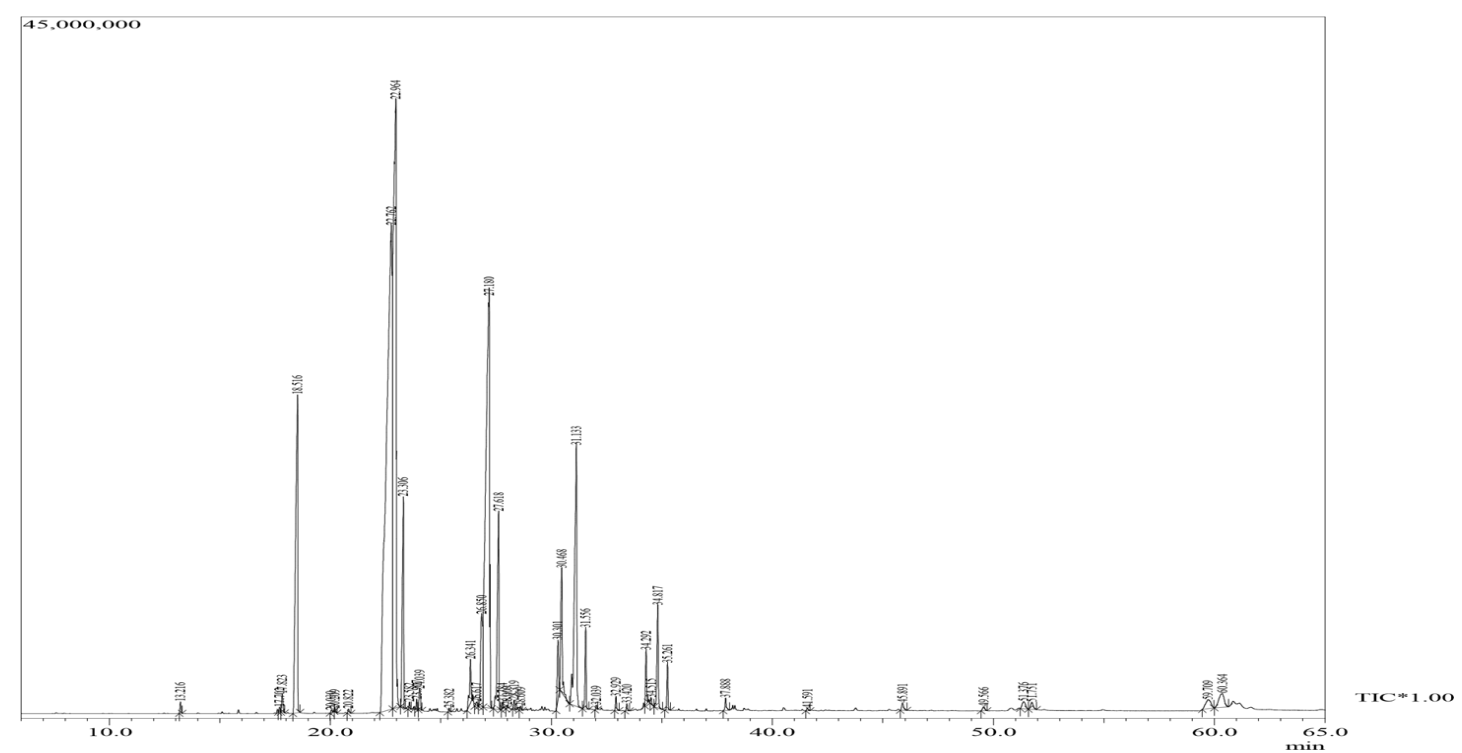

Fig. 5. GC-MS Chromatogram of produced biodiesel from Camelina seed oil.

biodiesel in airtight containers by providing oxygen-free atmosphere and adding antioxidants to the biodiesel. Rancidity of an oil is generally evaluated in terms of oxidation stability. It was also interesting to note that CBD exhibited a remarkable oxidation stability of about $6 \mathrm{~h}$. All examined parameters are shown in Table 3.

The major characteristics, such as AV, FFA\%, Sp. gravity and moisture contents were in the acceptable limits specified by the ASTM standards. After TE, obtained oil's saponification value was decreased up to 168.3. It indicated that triglyceride of CBD has high molecular mass of fatty acids than the CSO. The observed values of SV were favourable than SV values of other vegetable oils generally used for biodiesel production (Jibril et al., 2012). Peroxide Value (PV) is the measure of hydro peroxide concentration present in one $\mathrm{kg}$ of oil. PV for CBD was $13.28 \mathrm{Meq} / \mathrm{Kg}$ which was higher in comparison to the Jatropha produced BD, i.e. approximately $6 \mathrm{Meq} / \mathrm{Kg}$ reported by the other investigators (Akbar et al., 2009). IV of biodiesel was $152 \mathrm{gl}_{2} / 100 \mathrm{~g}$ which was higher than the specified limit of ASTM standards.

Oxidation stability (OS) of the obtained CBD was $6 \mathrm{hrs}$. which was higher than the minimum limit specified by ASTM (3 hrs.). But, still oxidation stability value was not much enough compared to other oilseed crops utilized as a feedstock for biodiesel production such as Jatropha, Sunflower, and Castor oil (Chaithongdee et al., 2010; Chellappa et al., 2019). However, having a high content of MUFA and PUFA this much oxidation stability was noticeable and it was may be due to the presence of antioxidant components such as vitamin $E$ 
Table 3. Characterization of Camelina produced biodiesel and its comparison with the ASTM, 2000 standard limits.

\begin{tabular}{|c|c|c|c|c|c|}
\hline S. No. & Properties & Test method & Unit & CS biodiesel & $\begin{array}{l}\text { ASTM, } 2000 \\
\text { D6751 Limits }\end{array}$ \\
\hline 1. & Yield Conversion & - & $(\%)$ & 92.28 & - \\
\hline 2. & Colour & - & - & Clear liquid & - \\
\hline 3. & Odor & - & - & Agreeable & - \\
\hline 4. & Moisture Content & IS 548 & $(\%)$ & 0.032 & $0.050 \max$ \\
\hline 5. & Specific Gravity & - & - & 0.873 & 0.88 \\
\hline 6. & Refractive Index & - & - & 1.33 & - \\
\hline 7. & Acid Value & IS 548 & $\mathrm{Mg} \mathrm{KOH} / \mathrm{g}$ & 0.37 & 0.5 \\
\hline 8. & FFA & IS 548 & $(\%)$ & 0.185 & - \\
\hline 9. & Saponification Value & FSSAI & $\mathrm{Mg} \mathrm{KOH/g}$ & 168.3 & - \\
\hline 10. & Ester Value & - & $\mathrm{Mg} / \mathrm{g}$ & 173.53 & - \\
\hline 11. & Peroxide Value & IS 548 & $\mathrm{Meq} / \mathrm{Kg}$ & 13.28 & - \\
\hline 12. & lodine Value & FSSAI & $\mathrm{gl}_{2} / 100 \mathrm{~g}$ & 152 & $150 \max$ \\
\hline 13. & Pour Point & ASTM, 2000 D97 & ${ }^{\circ} \mathrm{C}$ & -7 & $-15-10$ \\
\hline 14. & Cloud Point & ASTM, 2000 D2500 & ${ }^{\circ} \mathrm{C}$ & 3 & $-3-12$ \\
\hline 15. & Gross Calorific Value & ASTM, 2000 D240 & $\mathrm{Cal} / \mathrm{g}$ & 10745 & - \\
\hline 16. & Sulphur Content & ASTM, 2000 D5185 & PPM & 24 & 15 \\
\hline 17. & Flash Point & IP170 & ${ }^{\circ} \mathrm{C}$ & 126 & $120 \min$ \\
\hline 18. & Water \& sediments & ASTM, 2000 D1744 & $\%(\mathrm{~V} / \mathrm{V})$ & 0.02 & - \\
\hline 19. & Oxidation Stability at $110^{\circ} \mathrm{C}$ & ASTM, 2000 D2274 & Hours & 6 & $3 \mathrm{~min}$ \\
\hline 20. & Distillation Recovery 95\% & ASTM, 2000 D1160 & ${ }^{\circ} \mathrm{C}$ & 308 & - \\
\hline 21. & Corrosion (Fe \& Cu) & ASTM, 2000 D6595 & PPM & NILL & - \\
\hline 22. & Carbon Residue & ASTM, 2000 D524 & $\%(m / m)$ & 0.023 & 0.3 (Max) \\
\hline 23. & Particle count \& distribution & NAS 1638 & NAS Class & 4 & - \\
\hline
\end{tabular}

and some phenolic acids. The sulphur content of the CBD (24 ppm) was higher than the ASTM limits (15 ppm). The higher sulphur content was reported in the $\mathrm{CBD}$, because Camelina plant is from the Brassicaceae family, which contains glucosinolates (sulphurcontaining glucosides) as a main bioactive component and also responsible for the pungent smell of mustard family's plants (Barba et al., 2016). All Other fuelspecific properties such as pour point, cloud point, flash point, particle count, water and sediments, and carbon residue were under the specified ASTM fuel specification limits.

\section{Conclusion}

The higher oil yield and conversion of oil to biodiesel percentage indicated that the Camelina plant could be utilized as a primary feedstock for biodiesel production. However, FAME profiling of Camelina exhibited a higher number of unsaturated fatty acids, which the genetic modifications can reduce. Silica Gel deacidification was the principal part of the current investigation as this technique is not utilized beforehand by any analyst for the refining procedure of the Camelina oil. SG showed its adequacy for neutralizing the oil and high oil recovery was the additional advantage of this process. However, silica gel utilisation also needs some more research, including reaction time, temperature effects, and other such parameters. Yet, from this investigation, it can be concluded that this SG deacidification demonstrated positive outcomes in terms of recovered oil percentage, acid value reduction and density of the oil. Conversion of Camelina oil to Camelina biodiesel succeeded successfully. Besides sulphur content and lodine Value (IV), all the ester and fuel-specific properties were very much satisfactory and met all the ASTM standard limits specified for biodiesel.

\section{ACKNOWLEDGEMENTS}

The authors are grateful to the Director, DIBER-DRDO, for providing logistic laboratory facilities. Thanks are also to HOD, Department of Chemistry, DSB Campus, Nainital for the financial aid provided by DRDO, New Delhi, India is duly acknowledged.

\section{Conflict of interest}

The authors declare that they have no conflict of interest. 


\section{REFERENCES}

1. AOCS (2004). Official methods and recommended practices of the American Oil Chemists' Society. Champaign, USA: AOCS Publishing.

2. Akbar, E., Yaakob, Z., Kamarudin, S. K., Ismail, M., and Salimon, J. (2009). Characteristic and composition of Jatropha curcas oil seed from Malaysia and its potential as biodiesel feedstock. Eur. J. Sci. Res., 29(3), 396-403. http://citeseerx.ist.psu.edu/viewdoc/download? doi=10.1.1.1076.5372\&rep=rep1\&type=pdf

3. ASTM D. (2002). 6751-02, Standard Specification for Biodiesel Fuel (B100) Blend Stock for Distillate Fuels. Annual Book of ASTM, 2000 Standards. Accessed July 2020. https://afdc.energy.gov/fuels/biodiesel_specifications.html

4. Barba, F. J., Nikmaram, N., Roohinejad, S., Khelfa, A., Zhu, Z., and Koubaa, M. (2016). Bioavailability of glucosinolates and their breakdown products: impact of processing. Front. Nutr., 3, 24. https://doi.org/10.3389/ fnut.2016.00024

5. Barabas, E. S., and Brittain, H. G. (1998). Povidoneiodine. Analytical profiles of drug substances and excipients, 25, 341-462. https://www.sciencedirect.com/book series/analytical-profiles-of-drug-substances-andexcipients/vol/25/suppl/C

6. Barret, R. (2018). Importance and Evaluation of Lipophilicity. In: R. Barret Therapeutical Chemistry, pp. 53-78. Elsevier (2018). http://scholar.google.com/scholar_look up?hl=en\&publication_year=2018\&author=R.+Barret\&ti tle=Therapeutical+Chemistry

7. Berti, M., Gesch, R., Eynck, C., Anderson, J., and Cermak, S. (2016). Camelina uses, genetics, genomics, production, and management. Ind Crops Prod., 94, 690710. DOI: 10.1016/j.indcrop.2016.09.034

8. Biofuel Policy. (2018). Biofuels. National Policy on Biofuels-2018 retrieved from http://petroleum.nic.in/sites/ default/files/biofuels.pdf

9. Chaithongdee, D., Chutmanop, J., \& Srinophakun, P. (2010). Effect of antioxidants and additives on the oxidation stability of jatropha biodiesel. Agric. Nat. Resour. 44 (2), 243-250. https://li01.tci-thaijo.org/index.php/anres/ article/view/244911/167382

10. Chellappa, T., Santa Rosa, J. G., Santos, D. L., Boufleur, R. N., Paiva, I. V., Lèger, T., ... \& Nascimento, R. M. (2019). Oxidative stability of blended sunflower and castor biodiesel by Rancimat and static mode P-DSC. Energy Sources, Part A: Recovery, Utilization, and Environmental Effects, 1-10. https://doi.org/10.1080/15567036.2019.1678 697

11. Christy, A. A. (2012). Effect of heat on the adsorption properties of silica gel. Int. J. Eng. Technol., 4(4), 484-488. https://uia.brage.unit.no/uia-xmlui/handle/11250/1368 97.

12. Dalei, N. N., Roy, H., \& Gupta, A. (2017). Crude oil import of India from its major oil trade partner countries: An empirical evidence using panel data analysis. Int. j. adv. res. dev. 2(6), 726-735.

13. Demirbas, A., Bafail, A., Ahmad, W., and Sheikh, M. (2016). Biodiesel production from non-edible plant oils.
Energy Explor. Exploit., 34(2), 290-318. https://doi.org/1 $0.1177 / 0144598716630166$

14. Jibril, M., Joel, A. S., Edith, U., and Audu, A. A. (2012). Production and characterization of biodiesel from jatropha oil and neem oil. IJETED 2(2), 313-320. https://scholar.go ogle.com/scholar?hl=en\&as_sdt $=0 \%$

2C5\&q=Production+and+Characterization+of+Biodiesel+fr om+Jatropha+Oil+and+Neem+Oil\&btnG $=$

15. Kumar, K., and Pathak, R. (2016). Phytochemical analysis and assessment of in vitro antibacterial activity of nonpolar solvent based Camelina seed extracts. Indian J. Plant Physiol., 21(3), 255-262. https://doi.org/10.1007/ s40502-016-0223-6

16. King, A. J., He, W., Cuevas, J. A., Freudenberger, M., Ramiaramanana, D., and Graham, I. A. (2009). Potential of Jatropha curcas as a source of renewable oil and animal feed. J. Exp. Bot., 60(10), 2897-2905. https://doi.or g/10.1093/jxb/erp025

17. Mamat, R., Sani, M. S. M., Sudhakar, K., Kadarohman, A., \& Sardjono, R. E. (2019). An overview of Higher alcohol and biodiesel as alternative fuels in engines. Energy Reports, 5, 467-479. https://doi.org/10.1016/j.egyr.2019.04.0 09

18. Murphy, E. J. (2016). Camelina (Camelina sativa). In Ind Crop Prod. (pp. 207-230). https://doi.org/10.1016/ B978-1-893997-98-1.00008-7

19. Onukwuli, D. O., Emembolu, L. N., Ude, C. N., Aliozo, S. O., and Menkiti, M. C. (2017). Optimization of biodiesel production from refined cotton seed oil and its characterization. Egypt. J. Pet., 26(1), 103-110. https://doi.org/10.1 016/j.ejpe.2016.02.001

20. Pandey, V. C., Singh, K., Singh, J. S., Kumar, A., Singh, B., and Singh, R. P. (2012). Jatropha curcas: A potential biofuel plant for sustainable environmental development. Renew. Sust. Energ. Rev., 16(5), 2870-2883. https://doi.org/10.1016/j.rser.2012.02.004

21. Pinzi, S., Leiva, D., Lopez $\square$ Garcia, I., Redel $\square$ Macias, M. D., and Dorado, M. P. (2014). Latest trends in feedstocks for biodiesel production. Biofuel Bioprod Biorefin, 8(1), 126-143.https://doi.org/10.1002/bbb.1435

22. Richard Fleenor, (2011). USDA NRCS Plant Materials Program, Spokane WA. (Accessed on December, 2020). https://plants.usda.gov/plantguide/pdf/pg_casa2.pdf

23. Sbesta (2020). Profiling the world's top five countries in electricity consumption. https://www.nsenergybu siness.com/features/electricity-consuming-countries/

24. Villanueva-Mejia, D., \& Alvarez, J. C. (2017). Genetic improvement of oilseed crops using modern biotechnology. Advances in seed biology. Web of Science ${ }^{\mathrm{TM}}$ Core Collection (BKCl), 295-317.

25. Wang, D., Zhang, J., Yang, Q., Li, N., and Sumathy, K. (2014). Study of adsorption characteristics in silica gelwater adsorption refrigeration. Appl. Energy, 113, 734741. DOI: 10.1016/j.rser.2013.09.023

26. Zaliha, O., Chong, C. L., Cheow, C. S., Norizzah, A. R., \& Kellens, M. J. (2004). Crystallization properties of palm oil by dry fractionation. Food Chem., 86(2), 245-250. https:// doi.org/10.1016/j.foodchem.2003.09.032 